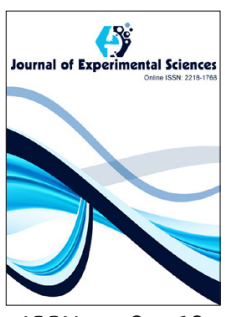

ISSN: 2218-1768
Received: April 15, 2020 Accepted: May 12, 2020 Published: May 16, 2020

*Corresponding Author: M.M. Shah,

Email:mmanjurshah@gmail. com

\section{Phytochemical screening and antifungal potentials of Citrus limon peels against Fusarium oxysporum and Rhizopus stolonifer causing rots in water melon (Citrullus lanatus L.)}

\author{
L. U. Bashir, A. Abdulkadir, M. M. Shah*, A. Hamisu, U. Sharif, A. A. Kamalu \\ Department of Biological Sciences, Yusuf Maitama Sule University, Kano, Nigeria
}

\begin{abstract}
This study investigated the phytochemical constituents and antifungal potential of Citrus limon peels using aqueous and methanol extracts against Fusarium oxysporum and Rhizopus stolonifer causing rots in water melon. The result of phytocemical screening revealed the presence of Saponin, Tannin, Phenols, Alkaloid and Flavanoid. Pathogenicity test conducted showed that F. oxysporum and R. stolonifer causes rots of Citrullus lanatus. The extracts inhibited the growth of F. oxysporum ( $76.67 \%$ and $60.00 \%$ ) methanol and aqueous respectively. R. stolonifer growth was inhibited (85.93\% and $71.11 \%$ ) methanol and aqueous extracts. The fungitoxicity of synthetic fungicide Benomyl was $95.56 \%$. The methanol extracts has highest inhibitory activity than aqueous extract. The result of the findings indicates the Biofungicide potentials of Citrus limon peels as alternative to synthetic fungicide in management of phyto-pathogens of water lemon.
\end{abstract}

KEYWORDS: Antifungal, phytochemical, fungicide, pathogenecity

\section{INTRODUCTION}

The persistent and promiscuous utilization of synthetic fungicides have exerted a serious threat to ecological balance and human health resulting in carcinogenic occurrences and resistance to the chemicals by the pathogenic fungi which poses a serious threat to plant and agricultural products. There is an increasing demand for the reduction in use of chemicals as antifungal agents in the field of agriculture and to combat various infectious plant diseases due to increasingly aggressiveness of endogenous phyto-pathogens that are resistant to the use of synthetic antifungal agents. With regards to the negative effects imposed by the use of synthetic chemicals in management of plant diseases, utilization of plants extracts in the course of managing plant diseases is gaining importance [6]. The perceived negative effect caused by synthetic fungicide, bactericide, herbicide, nematicide and pesticide/insecticide on agricultural land and water bodies as well as the risks involved in such activities, much attention was focused towards alternative method of pathogen control [5].

Citrus limon fruit is an important medicinal plants of the family Rutaceae, it is used mainly for its phytochemical constituents which are having anticancer and anti bacterial potentials in crude extracts of different parts viz, Leaves, stem, juice, peels and flower[18]. The fruits has wide spectrum of biological activities which include antibacterial, antifungal, antiviral activities due large constituents of phytochemicals [3]. The presence of arrays of phytochemicals such as saponins, steroids, tannins, glycosides, alkaloids, flavanoids and phenols in plants are responsible for antimicrobial activities $[9,17]$.

The water melon Citrullus lanatus is an important vegetable crop plant in Nigeria, cultivated mainly for its commercial edible fruits of high water and nutritional contents [12]. The origin of watermelon has been traced to Africa and the Middle East where it was cultivated for thousands of years, and in China since at least $900 \mathrm{AD}$. Watermelon was brought to the New World in the 1500 s. Watermelon is the fruit of a plant originally from a vine of southern Africa. It is a member of the cucurbitaceae family. The crop is grown commercially for it high water and nutritional contents of the fruits in areas with long frost-free warm periods[22]. The watermelon fruit has a smooth exterior rind and a juicy, sweet, usually red interior flesh. Watermelon (Citrullus lanatus L.) is a warm season crop in the Cucurbit family. Despite the commercial and nutritional importance of Citrillus lanatus

Copyright: $\odot$ The authors. This article is open access and licensed under the terms of the Creative Commons Attribution License (http://creativecommons.org/licenses/by/4.0/) which permits unrestricted, use, distribution and reproduction in any medium, or format for any purpose, even commercially provided the work is properly cited. Attribution - You must give appropriate credit, provide a link to the license, and indicate if changes were made. 
L. fruits, its production is beset by many phyto-pathogenic fungi such as F. oxysporum, F.solani. S. rofsii, A. niger, R. stolonifer, Rhizoctonia spp, Pythium spp. among others [10]. The aim of this study is to identify the phytochemical constituents of Citrus limon peels and to determine its antifungal effects on Growth inhibition of F. oxysporum and R. stolonifer causing fruit rot of Citrullus lanatus L.

\section{MATERIALS AND METHODS}

\section{Collection of Plant Materials}

Fresh Citrus limon were purchased from Nai'bawa yanlemo market and were identified and authenticated at the herbarium of plant pathology laboratory of Bayero University, Kano. A voucher specimen was deposited at the University herbarium with voucher number[18].

\section{Preparation of Extract of Citrus Limon Peels}

Fresh peels of C. limon were washed with tap water and air dried under natural conditions in the shade for a period of 7-10 days at an ambient room temperature. The dried materials were grounded to fine powder using sterile mortar and pestle to obtain the powdered form and kept in a sterile plastic bag for further use [8]. $25 \mathrm{~g}$ of the sample were subjected to successive extraction with water and methanol using Soxhlet apparatus for 5 hours at a temperature not exceeding the boiling point of the solvent [21]. The solvent extracts were removed by evaporation using water bath at $45^{\circ} \mathrm{C}$, the crude extracts obtained were weight and directly used for qualitative phytochemical screening and determination of antifungal activity [23].

\section{Collection of Sample}

Citrullus lanatus fruits (Water melon) showing symptoms of rots were randomly selected from different market stalls and local storage facilities in Naibawa Yanlemo market of Kano metropolis, healthy fresh blemish free Water melons were also collected and packaged in different sterile polythene bags and taken to Plant pathology laboratory of Department of Biological Sciences Bayero University, for microbial analysis.

\section{Isolation and Identification and of Rot Fungi}

To isolate the pathogens responsible for the rots on the affected water melon fruits, the fruits showing discolouration and sign of rots were cut into smaller pieces and surface sterilized in $1 \%$ Sodium hypochlorite solution for $60 \mathrm{sec}$. These were then rinsed in three successive changes of sterile distilled water and blotted dry with sterile filter paper. Small segments of tissues $\left(3 \mathrm{~mm}^{3}\right)$ from the margins of rotted lesions were cut out with a sterile scalpel and plated on potato dextrose agar (PDA) in $90 \mathrm{~mm}$ Petri - dishes. The plates were incubated at room temperature $\left(28 \pm 3^{\circ} \mathrm{C}\right)$ for 7 days. Developing fungal colonies were sub - cultured continuously on fresh PDA plates to obtain pure culture of the isolates. Fungal isolates, F. oxysporum and
R. stolonifer were identified based on cultural and morphological characteristics using mycological atlas $[7,19]$.

\section{Pathogenicity Test}

Fresh, healthy blemish free water melon fruits onion bulbs were washed with tap water, rinsed with distilled water and surface sterilized with $70 \%$ ethanol. Cylindrical discs were removed from the fruits with a sterile $4 \mathrm{~mm}$ cork borer. A disc of a five days old culture of the isolated F.oxysporum was transferred into hole created in the fruits. The plug was carefully placed and the wounded area sealed with Vaseline to prevent extraneous infection. The inoculated fruits were placed in separate air tight containers and incubated for 14 days at room temperature $\left(28 \pm 2^{\circ} \mathrm{C}\right)$. The same procedure was used for the control except that discs of uninoculated PDA were placed in the holes created in the fruits [4]. Three replications were prepared for treatment and control. After incubation period, the water melon fruits were examined for infection and disease development. The causal agents were re-isolated from the infected fruits and compared with the original isolates, the same procedure were done for R. stolonifer.

\section{In Vitro Antifungal Activities of Plant Extracts}

Poison food technique was used to determine the antifungal effects of the different concentrations of the plant extracts. For testing the antifungal effects of aqueous and methanol extracts of peels of C. limon four different concentrations were used; $500 \mathrm{mg} / \mathrm{ml}, 250 \mathrm{mg} / \mathrm{ml}, 125 \mathrm{mg} / \mathrm{ml}, 62.5 \mathrm{mg} / \mathrm{ml}$. $100 \mathrm{ml}$ sized conical flask was used for the experiment in each of the flask, $15 \mathrm{mls}$ of the media was poured, plugged with cotton wool and capped with aluminum foil. $5 \mathrm{ml}$ each of varying concentration of the peels extract were incorporated into each flask containing $15 \mathrm{ml}$ each of the media, these were then poured into pre-sterilized Petri-dishes and kept at room temperatures of $25^{\circ} \mathrm{C} \pm 2^{\circ} \mathrm{C}$, the seven days purified cultures were punched with sterile cork borer $(2 \times 2 \mathrm{~mm})$ and impregnation was made with the aid of sterile inoculating needle and then deposited at the center of the petri-dishes containing varying concentrations. The plates which contained synthetic Benomyl as well as $20 \mathrm{ml}$ of media and no treatment serve as positive and negative control. Impregnation were made and the seven days purified cultures were punched with sterile cork borer $(2 \times 2 \mathrm{~mm})$ which was deposited at the center of the plate. The result was measured in millimeter $(\mathrm{mm})$ by measuring the fungal growth from two lines (vertical and horizontal) and the mean were recorded [30]. For each treatment, three (3) replicates were maintained. The antifungal activities in terms of percentage growth inhibition (PGI) of the mycelial growth was calculated [29].

$$
P G I=\frac{d c-d t}{d c} \times 100
$$

Where $d c=$ Average mycelial growth in control plates

$d t=$ Average mycelial growth in treated plates

PGI $=$ Percentage growth inhibition 


\section{Phytochemical Screening of C. Limon Peels Extract}

Phytochemical screening were conducted to qualitatively determine the presence or absence of the following secondary metabolites which are alkaloids, tannins, flavonoids, saponins and phenol using methods outlined $[33,14,15,31]$.

\section{Test for Saponins}

a) $5 \mathrm{ml}$ of distilled water was added to $2 \mathrm{ml}$ of the extracts in a test tube and shaken thoroughly. The formation of foams or stable frothing after shaken indicates the presence of saponins [14].

b) $0.5 \mathrm{~g}$ of each extracts was separately shaken with distilled water in a test tube followed b y heating in a water bath to a boiling point. Persistent frothing on warming confirms the presence of saponins [33].

\section{Test for Tannins}

Few drops of $\mathrm{FeCl}_{2}, 5 \% \mathrm{~W} / \mathrm{V}$ ) solution was added to $2-3 \mathrm{ml}$ of the extracts in a test tube followed by shaking. A dirty green or dark blue coloration confirm the presence of Tannins [14].

\section{Test for Phenols}

One milliliter of the extract was added to $1 \mathrm{ml}$ of $10 \% \mathrm{FeCl}_{3}$ and mixed together. The presence of blue precipitate confirms the presence of Phenols [14].

\section{Test for Alkaloid}

$0.5 \mathrm{~g}$ of each extracts were stirred with $10 \mathrm{~cm}^{3}$ of $10 \%$ hydrochloric acid and was allowed to stand overnight and then divided into two parts for the following tests.

a. 2 drops of meyer's reagent was added to $1 \mathrm{~cm}^{3}$ of the extracts. Appearance of a creamy precipitate was taken as the evidence of the presence of Alkaloids [15].

b. 2 drops of wagner's reagent was added to $1 \mathrm{~cm}^{3}$ of the extracts. A reddish brown precipitate observed in each test tube indicates the presence of Alkaloids [14].

\section{Test for Flavanoids}

One milliliter of the extracts was treated with $1 \mathrm{ml}$ of dilute $\mathrm{NaOH}$. The presence of a cloudy precipitate confirms the presence of flavonoids [14].

\section{Data analysis}

All data obatained were statistically analyzed for significant difference $(P<0.05)$ by analysis of variance (ANOVA) and means were separated using Duncan Multiple Range Test (DMRT) [32].

\section{RESULTS AND DISCUSSIONS}

The phytochemical analysis of Citrus limon peels extracts are shown in Table 1. The result showed that Saponins, Tannins,
Phenols, alkaloids and flavanoids were present in methanol extract but only flavanoid was not observed in aqueous extracts, this may be due to solubility of the methanol is much more than that of aqueous solvent. Junab and Trideep[18] screened the phytochemical constituents of lemon peels the result revealed the presence of alkaloids, saponin, flavanoid, tannins glycosides and steroids which is in agreement with the results of this study where by most of the bioactive components screened were present.

Rutaceae family generally contain host of active phytochemicals like limonin, nomilin, octanol, cineole and naringin that inhibit fungal pathogens, this compounds occur in high concentrations in grape, lemon and orange fruits and are responsible for that bitter taste of the fruits[1,24]. Saponins were found in preliminary studies of the C. limon extracts, the presence of saponins may also be responsible for bitter taste and antifungal properties of this plant[25]. The presence of tannins and phenolic compounds in C. limon peels indicates that this plant have antimicrobial properties since phenols and phenolic compounds are extensively used in disease prevention and remain a standard with which other bactericides or fungicides are compared [24]. Okwu et al.. [25] reported high percentage of alkaloids and flavanoids in C. limon peels extracts which are in conformity with the preliminary screening of C. limon peels extracts in this study. Phenolics forms large group of naturally occurring, diverse and widespread compounds responsible for antifungal or bactericidal properties (Okwu et al., 2007).

The percentage growth inhibition of $F$. oxysporum aqueous and methanol C. limon peel extracts was shown in Table 2. The aqueous and methanol extracts at $(500 \mathrm{mg} / \mathrm{ml})$ showed highest \% inhibitory activities with $(60 \%$ and $76 \%)$ respectively, synthetic antifungal component Benomyl had (95.5\%) inhibition, low inhibitory activities were recorded at $(62.5 \mathrm{mg} / \mathrm{ml})$ with (14.8 and 39.9\%) aqueous and methanol extracts. The high inhibitory activities of methanol extract could be due to solvent solubility extraction of antifungal moieties and could be linked

Table 1: Phytochemical Analysis of aqueous and methanol peels extracts of Citrus limon L.

\begin{tabular}{lccccc}
\hline Plant/Solvent & Saponin & Tannin & Phenol & Alkaloid & Flavonoid \\
\hline Aqueous (C. limon) & + & + & + & + & - \\
Methanol (C. limon) & + & + & + & + & + \\
\hline
\end{tabular}

$(+)=$ presence; $(-)=$ Absence

Table 2: Antifungal activities (\% Growth Inhibition) of aqueous and methanol extracts of $F$. oxysporum (C. limon)

\begin{tabular}{lcc}
\hline Concentration $(\mathrm{mg} / \mathrm{ml})$ & \multicolumn{2}{c}{ F. oxysporum (C. limon) } \\
\cline { 2 - 3 } & Aqueous extract & Methanol extract \\
\hline 500 & $60.00^{\mathrm{b}} \pm 1.92$ & $76.67^{\mathrm{b}} \pm 1.70$ \\
250 & $44.81^{\mathrm{c}} \pm 1.85$ & $60.74^{\mathrm{c}} \pm 1.96$ \\
125 & $25.56^{\mathrm{d}} \pm 0.64$ & $45.19^{\mathrm{d}} \pm 0.98$ \\
62.5 & $14.81^{\mathrm{e}} \pm 2.06$ & $39.63^{\mathrm{e}} \pm 2.06$ \\
Benomyl & $95.56^{\mathrm{a}} \pm 0.00$ & $95.56^{\mathrm{a}} \pm 0.00$ \\
\hline
\end{tabular}

Values are mean \pm standard error of 3 replicates

$a, b, c$ Means in a column with different superscripts are significantly different $(P<0.05)$ 
to the fact that C. limon has large deposit of alkaloids and phenolic compounds which have antifungal properties[28]. The antimicrobial properties of plants extracts have been largely attributed to the presence of flavanoid and alkaloid compounds [13].

The percentage growth inhibition of $R$. stolonifer aqueous and methanol extract were presented in Table 3. The aqueous and methanol extract at $500 \mathrm{mg} / \mathrm{ml}$ had highest \% percentage inhibition of $(71 \%$ and $85 \%)$ aqueous and methanol extracts respectively. The synthetic fungicide Benomyl had (95.6) inhibition. Relatively moderate inhibition were recorded at $(250 \mathrm{mg} / \mathrm{ml})$ with $(60$ and $68 \%)$ aqueous and methanol extracts respectively. Lowest inhibitory activities were recorded at $(62.5 \mathrm{mg} / \mathrm{ml})$ with aqueous extract $(16.7 \%)$ inhibition.

Citrus plants contain phytochemical compounds such as limolin, nomilin,octanol,cineole and terpenoids that possesses antifungal properties, this components of phytochemical which occur in high concentrations in lemon, grapes and oranges are responsible for bitter taste in this fruits and inhibits the growth of bacteria and fungi [24]. The mechanism of inhibitory actions of phyochemicals such as alkaloids and phenolic compounds on micro organisms may be due to impairments of variety of enzymes systems in micro organisms including those involved in energy production, interference with the integrity of the cell membranes and structural components synthesisis(Huang and Chung, 2003).

According to Okwu et al. [25] 10\% concentrations of peels and leaf extracts of citrus and synthetic Benomyl have inhibited the growth of F. oxysporum by $(83.55 \%$ and $83.04 \%)$ respectively, this findings is in agreement with the present study which showed that $500 \mathrm{mg} / \mathrm{ml}$ lemon peels methanol extracts inhibited the growth of F. oxysporum by $76.67 \%$ and Benomyl 95.56\%. Citrus flavanoid have a large spectrum of biological activities including anti bacterial, antifungal, anti diabetic, anti cancer and anti viral activities [27]. Phenolic compounds are also considered to be bactereostatic and fungistatic. These compounds caused swelling of hyphal tips, plasma seeping around huphae, cell wall devastation, abnormal branching or fusion of hyphae and consequently wrinkling of hyphal surface [16]. Cowen[11] reported that lipophilic flavanoids may disrupt microbial membrane, Ahonkhai et al.. [2] reported that volatile oils of Citrus have anti microbial effects against bacteria and fungi. Lemon peels

Table 3: Antifungal activities (\% Growth Inhibition) of aqueous and methanol extracts on $R$. stolonifer (C. limon)

\begin{tabular}{lcc}
\hline Concentration $(\mathrm{mg} / \mathrm{ml})$ & \multicolumn{2}{c}{$R$. stolonifer (C. limon) } \\
\cline { 2 - 3 } & Aqueous extract & Methanol extract \\
\hline 500 & $71.11^{\mathrm{b}} \pm 1.70$ & $85.93^{\mathrm{b}} \pm 0.37$ \\
250 & $60.00^{\mathrm{c}} \pm 1.92$ & $68.52^{\mathrm{c}} \pm 1.61$ \\
125 & $32.96^{\mathrm{d}} \pm 1.34$ & $51.11^{\mathrm{d}} \pm 1.11$ \\
62.5 & $16.67^{\mathrm{e}} \pm 2.31$ & $38.89^{\mathrm{e}} \pm 1.70$ \\
Benomyl & $95.56^{\mathrm{a}} \pm 1.28$ & $95.56^{\mathrm{a}} \pm 1.28$ \\
\hline
\end{tabular}

Values are mean \pm standard error of 3 replicates

$a, b, c$ Means in a column with different superscripts are significantly different $(P<0.05)$ have high quantity of saponin with lytic properties against many strain of bacteria and fungi [20].

Plants stores different antifungal, anti bacterial and anti viral phytochemicals on the bark, leaves and exocarp of fruits for protection especially to preserve the fruits and protect the seeds from microbial attack. This is in agreement with the findings of Okwu and Emenike[26] who reported that phytochemicals are reserved in plants to protect the plants against invasion by pathogenic micro organisms. The extracts of peels of Citrus limon inhibited the growth of F. oxysporum and R. stolonifer significantly which is in agreement with the work of Okwu et al. [25]. Extracts of Citrus limon peels contains antifungal compounds that can be use as Biofungicides. The prospect of using Citrus peels as natural fungicides is encouraging as it is biodegradable, non toxic, environmentally friendly and safe to non target micro and macro flora and fauna, less resistance development in pathogenic pest and above all cheap and readily available. Based on these findings Citrus limon peels that are waste by-products, its extracts can be use to control and manage fungal disease of plants as alternative to synthetic fungicides.

\section{ACKNOWLEDGMENTS}

The authors are thankful to the Head, Department of Biological Sciences, Yusuf Maitama Sule University for providing necessary laboratory facilities.

\section{CONFLICT OF INTEREST}

The authors declare that there is no conflict of interest.

\section{REFERENCES}

1. Alais C, Linden G. Food Biochemistry. Aspen Publications, Maryland. 1999. 114-116.

2. Ahonkhai I, Ba A, Edogan O, Mu U. Antimicrobial activities of the volatile oils of Ocimum bacilicum and Ocimum gratissimum L. against some aerobic dental isolates. Pakista J. Pharm. Sci. 2009;22:405-409.

3. Akhilesh K, Raghvendra P, Vikas S, Madhulika G.Antimicrobial property of lemon peel extract. National Journal of Universal Pharmaceutical and Life Science. 2012;52:382-386.

4. Amienyo E, Ataga EA. Use of indigenous plants extracts for the protection of mechanically injured sweet potato (Ipomea batatas L) Tubers. Nigerian Journal of Microbiology. 2017;20(8): 1334-1338.

5. Amusa NA, Odumbaku OA. Biological control of bacterial diseases of plantrs in Nigeria: Problem and prospect. Research Journal of Agriculture and Biological Sciences. 2007;316:979-982.

6. Babu J, Muzaffar AD, Vinod K.Bioefficacy of plant extract to control Fusarium solani F.sp Melongenae incitant of brinjal wilt. Global Journal of Biotechnology and Biochemistry. 2008;3(2):56-59.

7. Barnett HL, Hunter BB. Illustrated Genera of Imperfect Fungi. Collier Macmilan, London 1987; 200-219.

8. Boateng B, Kusi F. Toxicity of Jatropha seed oil to Callasobruchus maculates (F) (Coleoptera: Bruchidae) and its parasitoid, Dinarmus basilis (Hymeneptera: Pteromalidae), Journal of applied Sciences Research, 2008;4 (8): 945-951.

9. Bukar A, Uba A,Oyeyi TI. Antimicrobial profile of Moringa oleifera lam. Extracts against some food - borne microorganisms. BAJOPAS. 2010;3 (1): 43-48.

10. Burgess LW, Knight TE, Tesoriero L, Phan HT.Diagnostic manual for plant diseases in Vietnam. ACIAR Monograph No 129. (Australian Centre for International Agricultural Research: Canberra) 2008.

11. Cowen MM. Plant products as antimicrobial agents. Clinical Microbiological Reviews. 1999;12, 564-582. 
12. Denton OA, Olufolaji AO.Nigeria's most important vegetable crops. In Agronomy in Nigeria. Polygraphics venture Ltd. Ibadan. 2000.P.32

13. El-Zawawy NA. Antioxidant, antitumor, antimicrobial studies and quantitative phytochemical estimation of ethanolic extracts of selected fruits peels. Internation Journal of Current Microbial and Applied Science. 2015;4(5): 298-309.

14. Evans WC, Trease. Pharmacognosy $14^{\text {th }}$ edition W.B Saunders Company Limited, New York. 1999:1-340.

15. Harborne JB. Phytochemical methods a guide to modern techniques of plant analysis $2^{\text {nd }}$ edition. Chapman and Hall, London, 1973;pp 1-13.

16. Huang JW, Chung WC. Management of vegetable crop diseases with plant extracts. 2003; pp.153-163.

17. Igbinosa O, Olgbinosa EO, Aiyegoro OA. Antimicrobial activity and phytochemical screening of stem bark extracts from Jatropha curcas (Linn). African Journal of Pharmacy and Pharmacology. 2009;3(2):058-062.

18. Junab A, Biswati D, Trideep S. Antimirobial activities of lemon peels Citrus Limon Extracts. International Journal of Current Pharmaceutical Research. 2017;9(4):79-82

19. Koneman E, Procop G, Shreckenberger P, Wood G, Janda W, Allen S, Winn CW. Konneman color Atlas and Diagnostic Microbiology. Lippincoth Williams and Wikkins London. 2006;1535pp.

20. Kumar KA, Narayani M, Subanthini A, Jayakumar M. Antimicrobial activity and phyochemical analysis of Citrus fruits peels-utilization of fruit waste. International Journal of Engineering Sciences and Technology. 2011;36(6): 5414-5421.

21. Lin CM, Sheu SR, Hsu SC, Tsai YH. Determination of bactericidal efficacy of essential oil extracted from orange peel on the food contact surfaces. Food Control. 2010;21, 1710-1715.

22. Majid N. Energy use and Cost Analysis of Watermelon Production under Different farming Technologies in Iran. International Journal of Environmental Sciences.2011; (6):1144- 1153

23. Mogle UP, Maske SR.Efficacy of bioagents and fungicides on seed mycoflora, germination and vigor index of cowpea. Science Research
Reporters. 2012;2(3): 321-326.

24. Okwu DE, Morah FNI. Antimicrobial and phytochemical evaluation of seed of Garcinia Kola and Dennettia tripetela fruits. Journal of Medicinal and Aromatic Plant Sciences. 2007;29:20-23.

25. Okwu DE, Awurum AN, Okoronkwo Jl. Phytochemical composition and in vitro antifungal activity screening of extracts from Citrus plants against Fusarium oxysporum of okra. Pest Technology. 2007;1(2) 145-148.

26. Okwu DE, Emenike IN. Evaluation of phytochemical constituents and vitamin contents of citrus fruits. International Journal of Molecular medicine and advanced Sciences 2006;2:1-6.

27. Ortuno AA, Baidez P, Gomez PMC, Arcas I, Porras AG, Del Rio JA. Citrus paradise and Citrus sinensis flavonoids: Their influence in the defence mechanism against Penicillium digitatum. Food Chememistry. 2006;98(2): 351-358

28. Patkowski E.Effectiveness of grape fruits extracts and pythium oligandrun in the control of beans and peas pathogen. Journal of Plant Protection Research. 2006;46:15-28.

29. Sharma SN, Chandel SS. Screening of biocontrol agents in vitro against Fusarium oxysporum F.sp. gladioli and their mass multiplication on different organic substrates. Plant Disease Research. 2003;18(2):35-38.

30. Sing A, Tripatti NN. Inhibition of storage fungi of black gram (Vigna mungo L.) by some essential oils. Flavour Fragrance Journal. 1999; $14: 42-44$

31. Singh B., Bhat T K. Potential therapeutic applications of some antinutritional plant secondary metabolites. Journal of Agriculture and Food Chemistry. 2003; 51:5579-5597.

32. Snedecor DGW, Cochran WG. Statistical methods, $6^{\text {th }}$ Ed. IOWA State University press U.S.A. 1967; 593 pp.

33. Sofowora A. Medicinal Plants and Medicine in Africa. John Whilley Spectrum Books, Ibadan, Nigeria. 1993; 120-123. 